doi.org/10.3114/fuse.2021.07.01

\title{
Pseudocercospora and allied genera associated with leaf spots of banana (Musa spp.)
}

\author{
P.W. Crous ${ }^{1,2,3^{*}}$, J. Carlier ${ }^{4}$, V. Roussel ${ }^{4}$, J.Z. Groenewald ${ }^{1}$
}

${ }^{1}$ Westerdijk Fungal Biodiversity Institute, P.O. Box 85167, 3508 AD Utrecht, The Netherlands

${ }^{2}$ Department of Biochemistry, Genetics and Microbiology, Forestry and Agricultural Biotechnology Institute (FABI), University of Pretoria, Pretoria, 0002 , South Africa

${ }^{3}$ Wageningen University and Research Centre (WUR), Laboratory of Phytopathology, Droevendaalsesteeg 1, 6708 PB Wageningen, The Netherlands ${ }^{4}$ Centre de Coopération International en Recherche Agronomique pour le Développement (CIRAD), TA 40/02, avenue Agropolis, 34398 Montpellier, France

*Corresponding author: p.crous@wi.knaw.nl

Key words:

multi-gene phylogeny

Mycosphaerella

new taxa

Sigatoka leaf spots

systematics

\begin{abstract}
The Sigatoka leaf spot complex on Musa spp. includes three major pathogens: Pseudocercospora, namely P. musae (Sigatoka leaf spot or yellow Sigatoka), P. eumusae (eumusae leaf spot disease), and P. fijiensis (black leaf streak disease or black Sigatoka). However, more than 30 species of Mycosphaerellaceae have been associated with Sigatoka leaf spots of banana, and previous reports of $P$. musae and $P$. eumusae need to be re-evaluated in light of recently described species. The aim of the present study was thus to investigate a global set of 228 isolates of $P$. musae, $P$. eumusae and close relatives on banana using multigene DNA sequence data [internal transcribed spacer regions with intervening 5.8S nrRNA gene (ITS), RNA polymerase II second largest subunit gene ( $r p b 2$ ), translation elongation factor 1-alpha gene (tef1), beta-tubulin gene (tub2), and the actin gene (act)] to confirm if these isolates represent $P$. musae, or a closely allied species. Based on these data one new species is described, namely $P$. pseudomusae, which is associated with leaf spot symptoms resembling those of $P$. musae on Musa in Indonesia. Furthermore, $P$. eumusae, $P$. musae and $P$. fijiensis are shown to be well defined taxa, with some isolates also representing $P$. longispora. Other genera encountered in the dataset are species of Zasmidium (Taiwan leaf speckle), Metulocladosporiella (Cladosporium leaf speckle) and Scolecobasidium leaf speckle.
\end{abstract}

Citation: Crous P, Carlier J, Roussel V, Groenewald JZ (2020). Pseudocercospora and allied genera associated with leaf spots of banana (Musa spp.). Fungal Systematics and Evolution 7: 1-19. doi: 10.3114/fuse.2021.07.01

Received: 1 September 2020; Accepted: 23 October 2020; Effectively published online: 30 October 2020

Corresponding editor: U. Braun

\section{INTRODUCTION}

Bananas (Musa spp.) originated from Indochina and South East Asia (Simmonds 1962), from where they spread across tropical and sub-tropical regions of the world, presently representing the fourth most economically important food crop after rice, wheat and maize (www.fao.org).

Bananas and plantains are, however, susceptible to several diseases that have been of serious concern to the industry, namely Fusarium wilt (Panama disease) caused by Fusarium odoratissimum (formerly F. oxysporum f. sp. cubense tropical race 4) (Maryani et al. 2019), Banana bunchy top virus (Stainton et al. 2015), and the Sigatoka leaf spot complex, which include the most serious leaf spot diseases of banana (Churchill 2011).

Species of the Sigatoka leaf spot complex have a confused taxonomic history, and were formerly treated in the genus Mycosphaerella, which was shown to be polyphyletic, representing numerous genera in the Mycosphaerellaceae (Crous et al. 2007, 2009, Videira et al. 2017), and in other families (Quaedvlieg et al. 2014). Species of the Sigatoka leaf spot complex are members of the genus Pseudocercospora (Arzanlou et al. 2008, Crous et al. 2013, Nakashima et al. 2016).
Taxonomically, Pseudocercospora was formerly placed in the order Capnodiales in the class Dothideomycetes, which is the largest and most diverse class of ascomycetous fungi (Haridas et al. 2020). However, the Capnodiales represent sooty moulds that grow superficially on plant surfaces, and are associated with honeydew produced by insects, whereas the genera of plant pathogenic fungi formerly placed in Capnodiales, were shown to be members of the order Mycosphaerellales (Abdollahzadeh et al. 2020).

More than 30 mycosphaerella-like species have in the past been associated with leaf spot diseases of banana (see list below). The primary agents of the Sigatoka leaf spot complex found on banana include $P$. musae (previously: Mycosphaerella musicola) causal agent of Sigatoka leaf spot or yellow Sigatoka; $P$. eumusae (previously: M. eumusae) causal agent of the eumusae leaf spot disease, and $P$. fijiensis (previously: $M$. fijiensis) causal agent of black Sigatoka or black leaf streak disease, which is the most aggressive and predominant member of the Sigatoka lead spot complex worldwide. Phylogenetic reconstruction based on a set of 46 conserved single-copy genes strongly supported an earlier evolutionary radiation of $P$. fijiensis from $P$. musae and $P$. eumusae (between 15 to 40 MYA, Chang et al. 2016). Although 
these species can be distinguished based on differences in morphology and symptomatology, considerable overlap exists among them, making definite identification only possible by means of additional markers such as DNA sequence data (Arzanlou et al. 2008). Furthermore, several previous records of $P$. musae might in fact belong to the recently described $P$. longispora, while the variation within P. eumusae (Crous \& Mourichon 2002, Arzanlou et al. 2008) also requires further analysis. Because the distribution and relative importance of the latter taxa remain insufficiently known, the aim of the present study was to investigate a global set of isolates to better elucidate the distribution of Pseudocercospora spp. associated with leaf spot diseases of banana.

\section{MATERIALS AND METHODS}

\section{Isolates}

The set of isolates studied is presented in Table 1. Isolates were sourced from the CBS and CIRAD collections and were collected from various countries. The isolates from the CIRAD collection were derived either from single conidia or ascospores as described in Zapater et al. (2008). They were assumed to belong to $P$. musae, $P$. eumusae or other species based on morphological observations in culture media or sequencing of the internal transcribed spacer regions with intervening 5.8S nrRNA gene (ITS) of the nrDNA operon. The isolates from CBS collection were also derived either from single conidia or ascospore as described by Crous et al. (1991) and Crous (1998). In the present study, colonies were sub-cultured on $2 \%$ potato-dextrose agar (PDA), oatmeal agar (OA), MEA (Crous et al. 2019), autoclaved banana leaf on $2 \%$ tap water agar (BLA), and incubated at $25^{\circ} \mathrm{C}$ under continuous near-ultraviolet light to promote sporulation. Reference strains and specimens of the studied fungi are all maintained from now in the CBS culture collection (CBS) of the Westerdijk Fungal Biodiversity Institute (WI), Utrecht, the Netherlands.

\section{DNA extraction, amplification (PCR) and phylogeny}

Fungal mycelium (Table 1) was scraped from the agar surface of cultures with a sterile scalpel and genomic DNA was isolated using the Wizard ${ }^{\circledR}$ Genomic DNA Purification Kit (Promega Corporation, WI, USA) following the manufacturers' protocols. Eight loci were amplified following previously published protocols. First, the partial ITS region was sequenced for all isolates included in this study (for amplification conditions, see Fan et al. 2018). Amplification of the partial DNA-directed RNA polymerase II second largest subunit gene $(r p b 2)$, the partial translation elongation factor 1-alpha gene (tef1) and the partial beta-tubulin gene (tub2) followed Braun et al. (2018), while the amplification of the partial actin gene (act) followed Videira et al. (2016). The resulting fragments were sequenced in both directions using the respective PCR primers and the BigDye Terminator Cycle Sequencing Kit v. 3.1 (Applied Biosystems Life Technologies, Carlsbad, CA, USA); DNA sequencing amplicons were purified through Sephadex G-50 Superfine columns (SigmaAldrich, St. Louis, MO) in MultiScreen HV plates (Millipore, Billerica, MA). Purified sequence reactions were analysed on an Applied Biosystems 3730xI DNA Analyzer (Life Technologies, Carlsbad, CA, USA). The DNA sequences were analysed and consensus sequences were computed using SeqMan Pro v. 13 (DNASTAR, Madison, WI, USA).

The sequences for each gene region were subjected to megablast searches (Zhang et al. 2000) to identify closely related sequences in the NCBI's GenBank nucleotide database. Sequences of the individual loci were aligned using MAFFT v. 7 (http:// mafft.cbrc.jp/alignment/server/index.html) (Katoh \& Standley 2013), and the alignments were then manually edited in MEGA v. 7.0.21. Sequence Matrix v. 1.8 (http://www.ggvaidya.com/ taxondna/) was used to concatenate the individual loci in various combinations. Phylogenetic trees on the combined datasets were generated using Bayesian analyses performed with MrBayes v. 3.2.7 (Ronquist et al. 2012) as explained in Braun et al. (2018) and Pseudocercospora individual gene trees were evaluated using distance and parsimony analyses with PAUP v. 4.0b10 (Swofford 2003). All resulting trees were printed with Geneious v. 11.1 .53 (http://www.geneious.com, Kearse et al. 2012) and the layout of the trees was done in Adobe Illustrator v. CC 2017.

\section{Morphology}

Slide preparations were mounted in clear lactic acid or Shear's mounting fluid. Observations were made with a Nikon SMZ25 dissection microscope, and with a Zeiss Axio Imager 2 light microscope using differential interference contrast (DIC) illumination and images recorded on a Nikon DS-Ri2 camera with associated software. Colony characters and pigment production were noted after $2-4$ wk of growth on MEA, PDA and OA (Crous et al. 2019) incubated at $25^{\circ} \mathrm{C}$. Colony colours (surface and reverse) were scored using the colour charts of Rayner (1970). Sequences derived in this study were deposited in GenBank (Table 1), the alignment in TreeBASE (www.treebase.org; study number 27043), and taxonomic novelties in MycoBank (www. MycoBank.org; Crous et al. 2004).

\section{RESULTS}

\section{Phylogeny}

Based on the blast results, the majority of strains belonged to Pseudocercospora musae (104 strains) and Pseudocercospora eumusae (48 strains), while other Pseudocercospora species included Pseudocercospora fijiensis (two strains), Pseudocercospora longispora (two strains) and five strains representing a novel Pseudocercospora species related to Pseudocercospora musae (Fig. 1). The remainder of the strains tentatively identified as Mycosphaerella musae based on symptomatology (seven strains), Zasmidium musae (five strains), Scolecobasidium musicola (= Ochroconis musicola) (four strains, Fig. 2), Parapallidocercospora thailandica (three strains), while one strain was identical to Pantospora guazumae and the last strain represented a Penicillium infection and was discarded from further analyses (Table 1).

Two Bayesian analyses were performed (Table 2); the first on a concatenated ITS/act/tef1/rpb2 alignment of Pseudocercospora sequences (Fig. 1) and the second on a concatenated ITS/act/ tef1/tub2 alignment of Scolecobasidium sequences (Fig. 2). The Pseudocercospora phylogeny (Fig. 1) delimits four known species clades, namely Pseudocercospora eumusae, Pseudocercospora fijiensis, Pseudocercospora longispora and Pseudocercospora musae, with five strains from Musa (Indonesia) clustering in a 


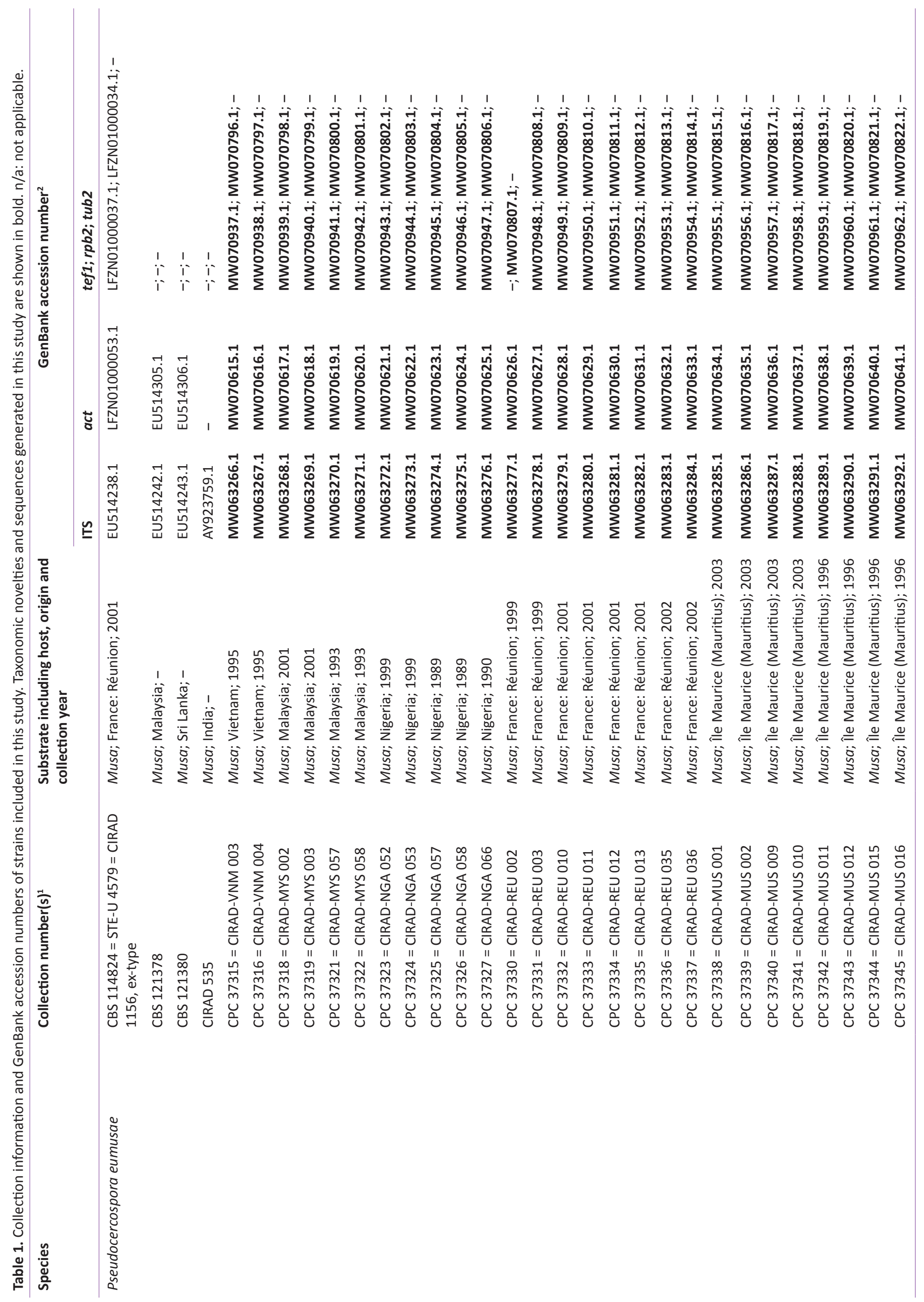




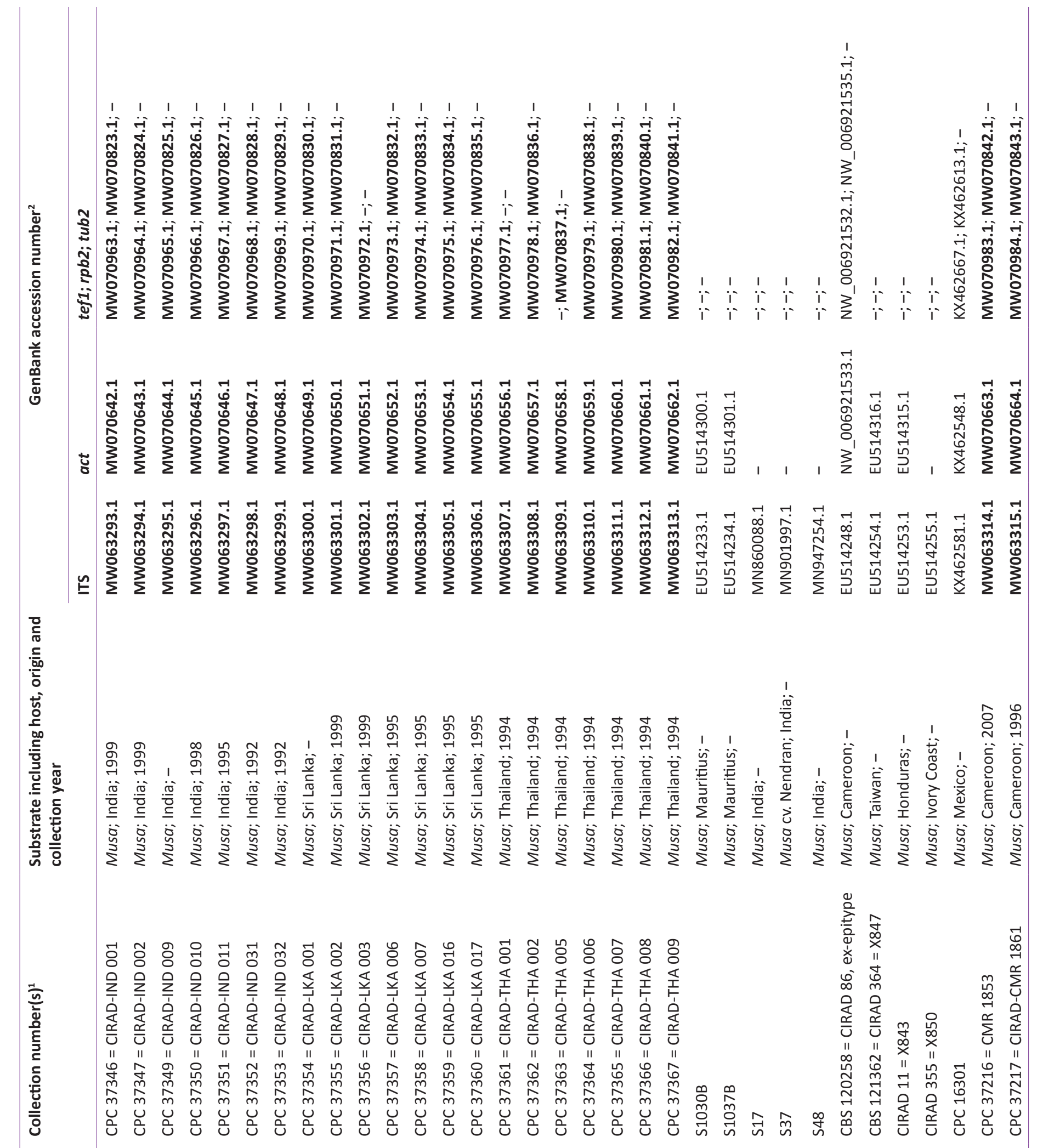




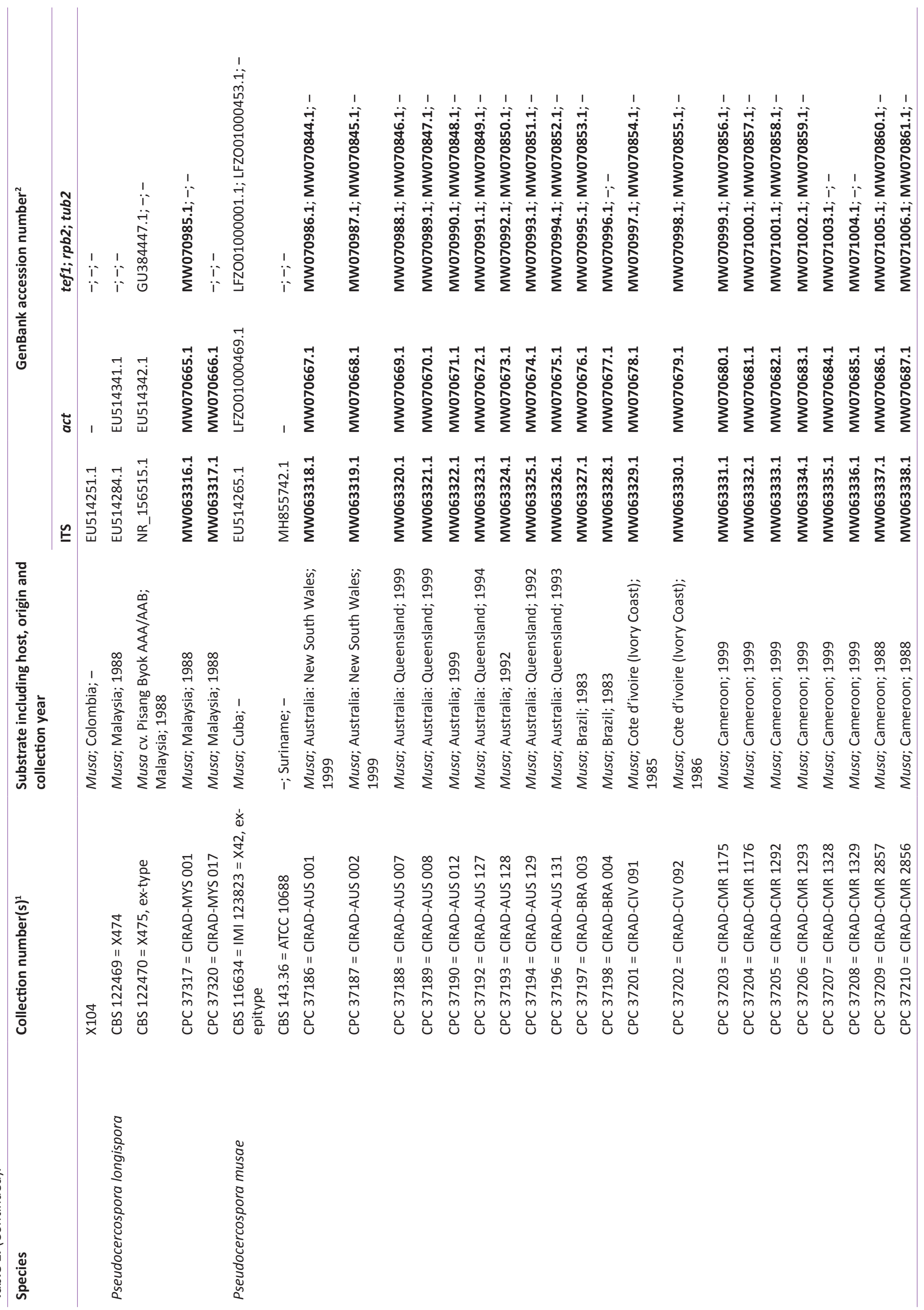




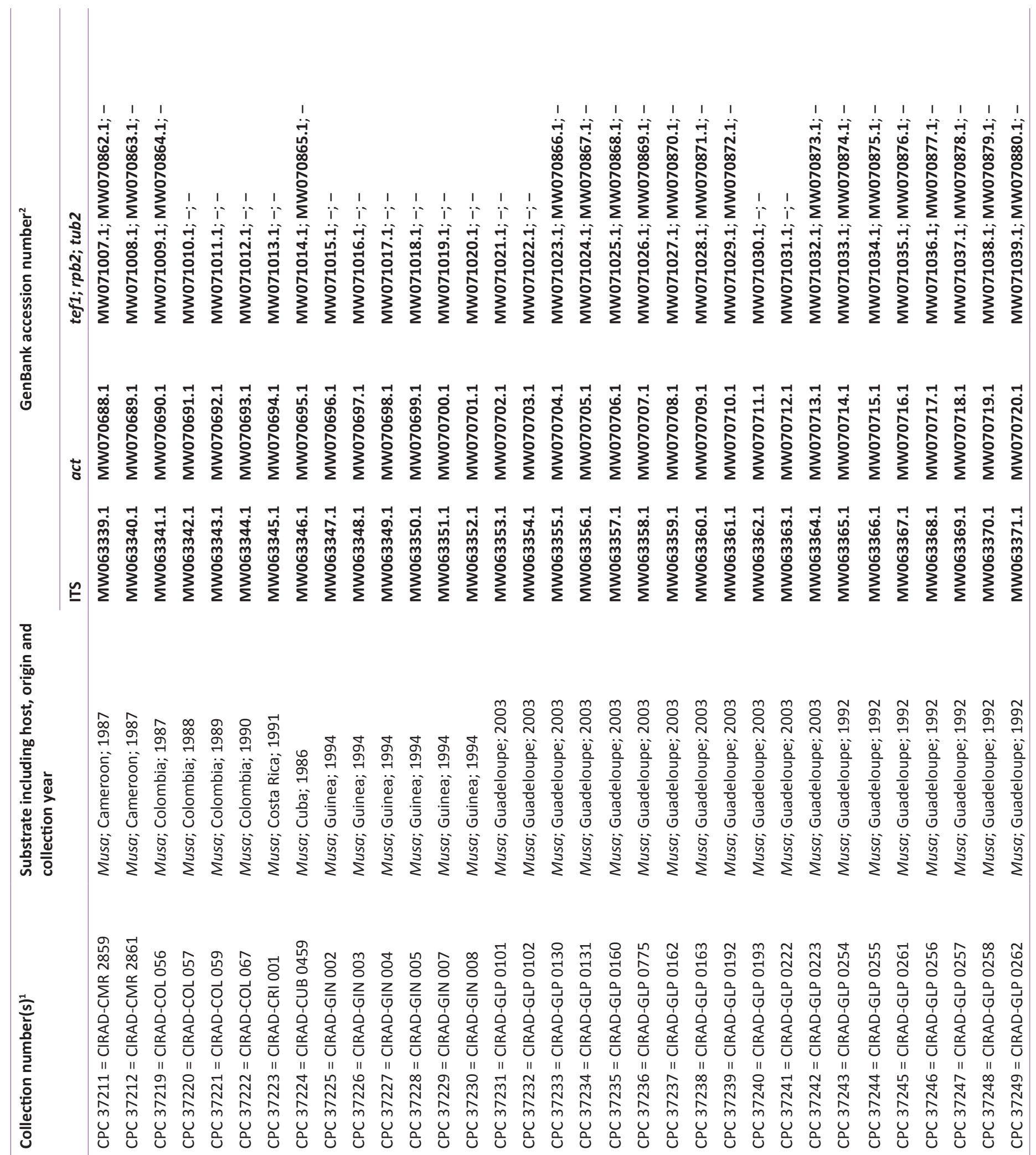

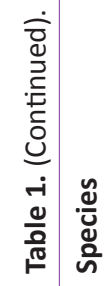




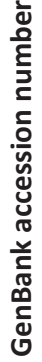

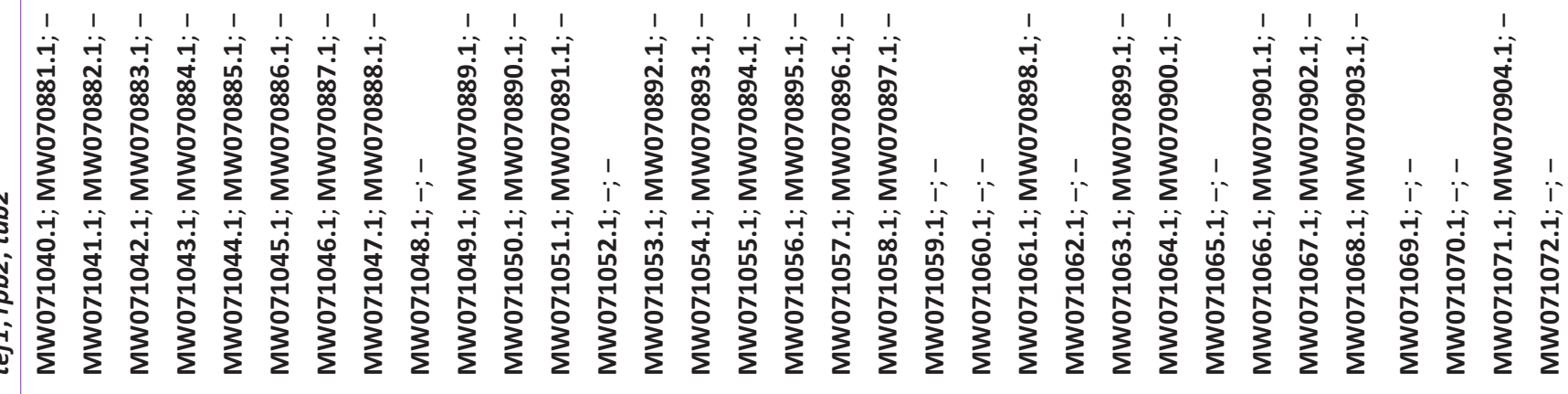

$\overleftarrow{\Xi}$

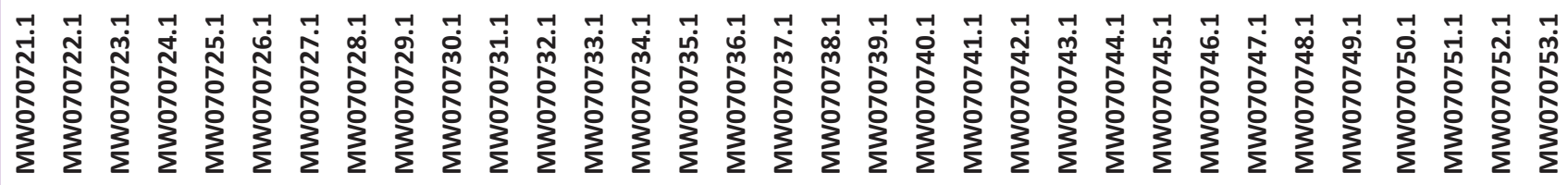

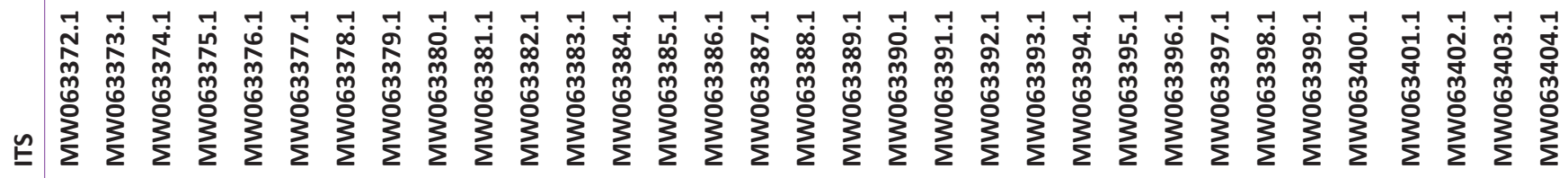

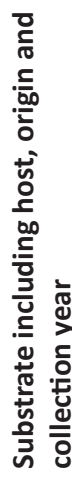

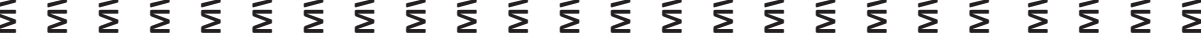

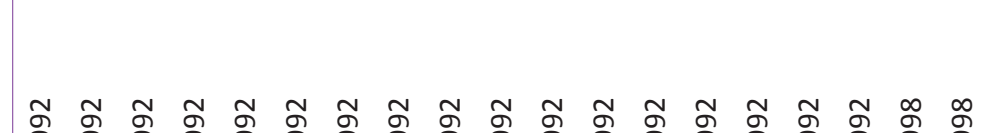

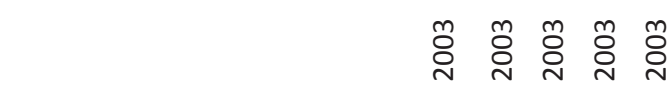

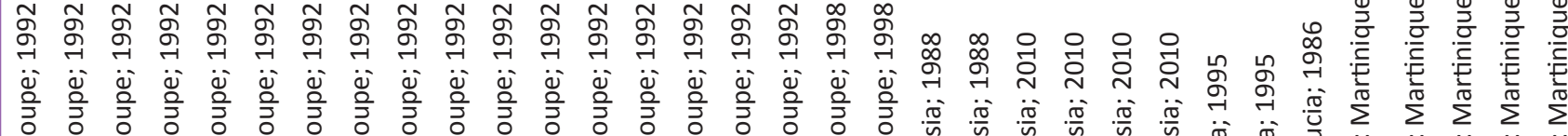

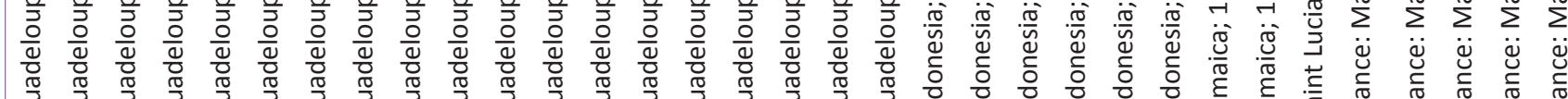

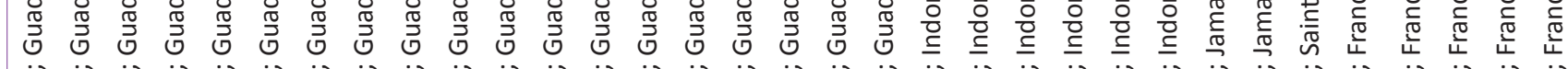

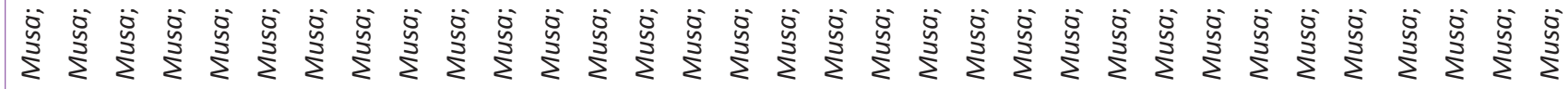

芯怘怘

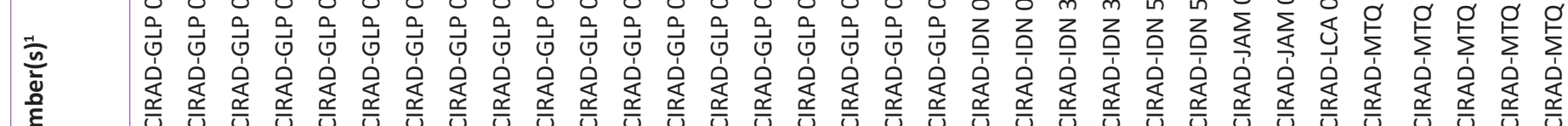

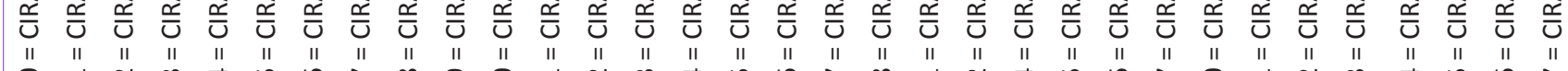

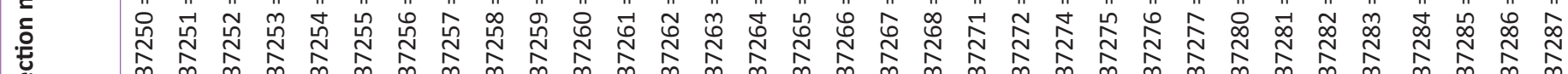

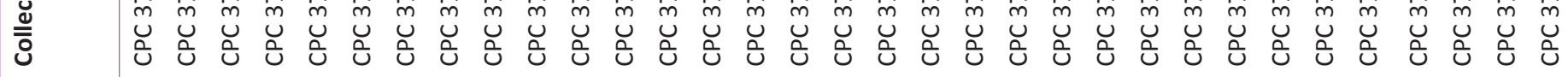




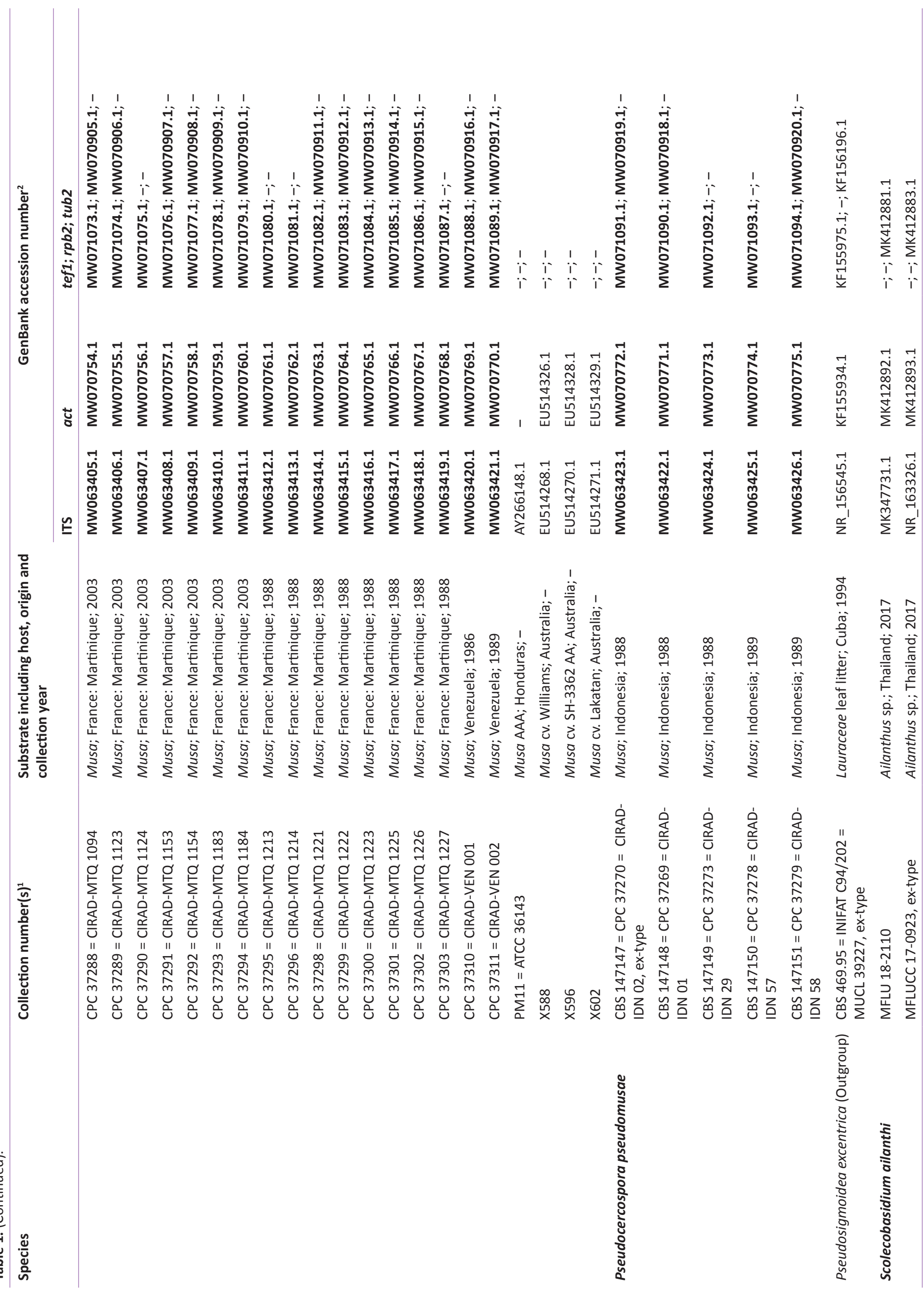




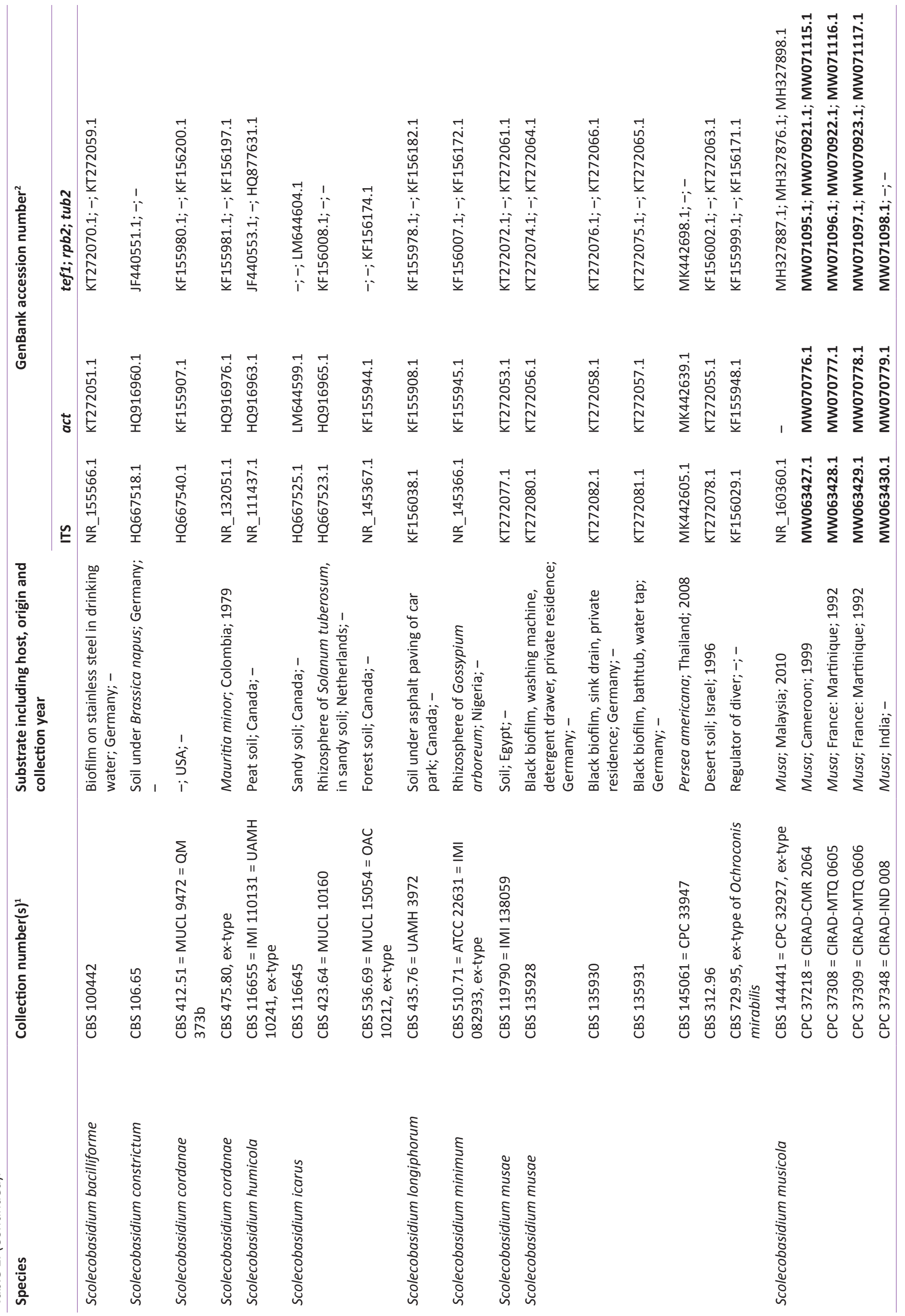




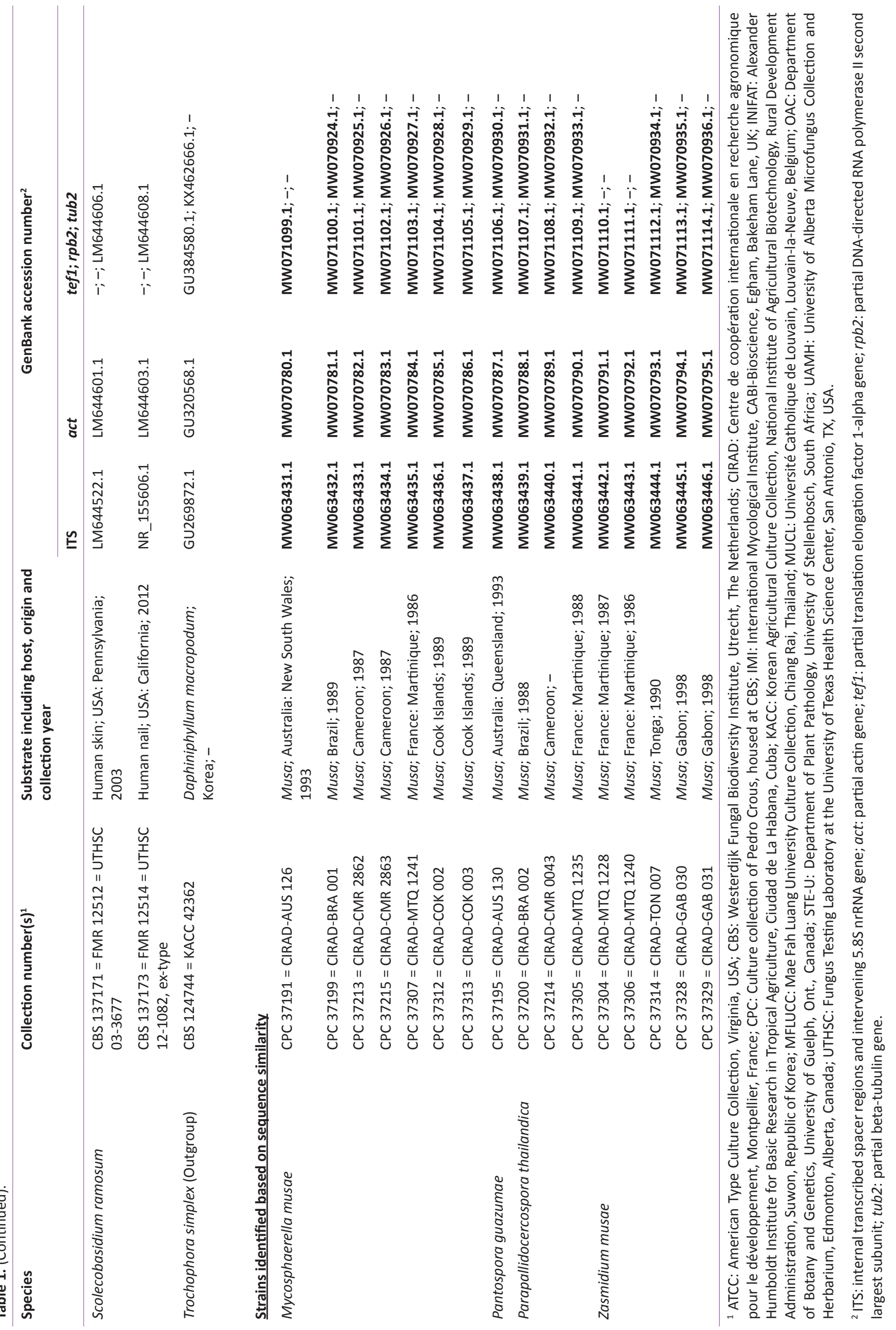


lineage sister to Pseudocercospora musae and representing a novel species which is described below. All five species clades were fully supported in the Bayesian analyses (posterior probability value of 1.0). Based on the Scolecobasidium phylogeny (Fig. 2), two strains are very closely related to the ex-type strain of Scolecobasidium musicola while two other strains form a closely related sister lineage. The two lineages have the following numbers of fixed nucleotide differences: ITS (19 substitutions and one indel), act (13 substitutions; no sequence available for the ex-type), tef1 (23 substitutions) and tub2 (8 substitutions and one indel; no sequence available for CPC 37348).

Trochophora simplex CBS 124744

CPC 37315 Musa Vietnam CPC 37316 Musa Vietnam CPC 37318 Musa Malaysia CPC 37319 Musa Malaysia CPC 37321 Musa Malaysia CPC 37322 Musa Malaysia CPC 37324 Musa Nigeria CPC 37325 Musa Nigeria CPC 37326 Musa Nigeria CPC 37327 Musa Nigeria CPC 37330 Musa Réunion CPC 37331 Musa Réunion CPC 37332 Musa Réunion CPC 37333 Musa Réunion CPC 37334 Musa Réunion CPC 37335 Musa Réunion CPC 37336 Musa Réunion CPC 37337 Musa Réunion CPC 37338 Musa Mauritius CPC 37339 Musa Mauritius CPC 37340 Musa Mauritius CPC 37341 Musa Mauritius CPC 37342 Musa Mauritius CPC 37343 Musa Mauritius CPC 37344 Musa Mauritius CPC 37345 Musa Mauritius CPC 37346 Musa India CPC 37347 Musa India CPC 37349 Musa India CPC 37351 Musa India CPC 37352 Musa India CPC 37353 Musa India CPC 37354 Musa Sri Lanka CPC 37355 Musa Sri Lanka CPC 37356 Musa Sri Lanka CPC 37357 Musa Sri Lanka CPC 37358 Musa Sri Lanka CPC 37359 Musa Sri Lanka CPC 37360 Musa Sri Lanka CPC 37361 Musa Thailand CPC 37362 Musa Thailand CPC 37363 Musa Thailand CPC 37364 Musa Thailand CPC 37365 Musa Thailand CPC 37366 Musa Thailand CPC 37367 Musa Thailand CBS 114824 Musa Réunion CBS 121378 Musa Malaysia CBS 121380 Musa Sri Lanka CIRAD 535 Musa India S1030B Musa Mauritius S1037B Musa Mauritius S17 Musa India S37 Musa cv. Nendran India S48 Musa India CPC 37323 Musa Nigeria CPC 37350 Musa India

Fig. 1. Consensus phylogram ( $50 \%$ majority rule) resulting from a Bayesian analysis of the multigene Pseudocercospora sequence alignment. Bayesian posterior probabilities (PP) $>0.84$ are shown at the nodes and thickened lines represent nodes with PP $=1.00$. The scale bar represents the expected changes per site. Species are indicated with coloured blocks to the right of the tree. Culture collection numbers are followed by the host and origin, where known. The tree was rooted to Trochophora simplex (culture CBS 124744). The taxonomic novelty described in this study and cultures with type status are indicated in bold face. 


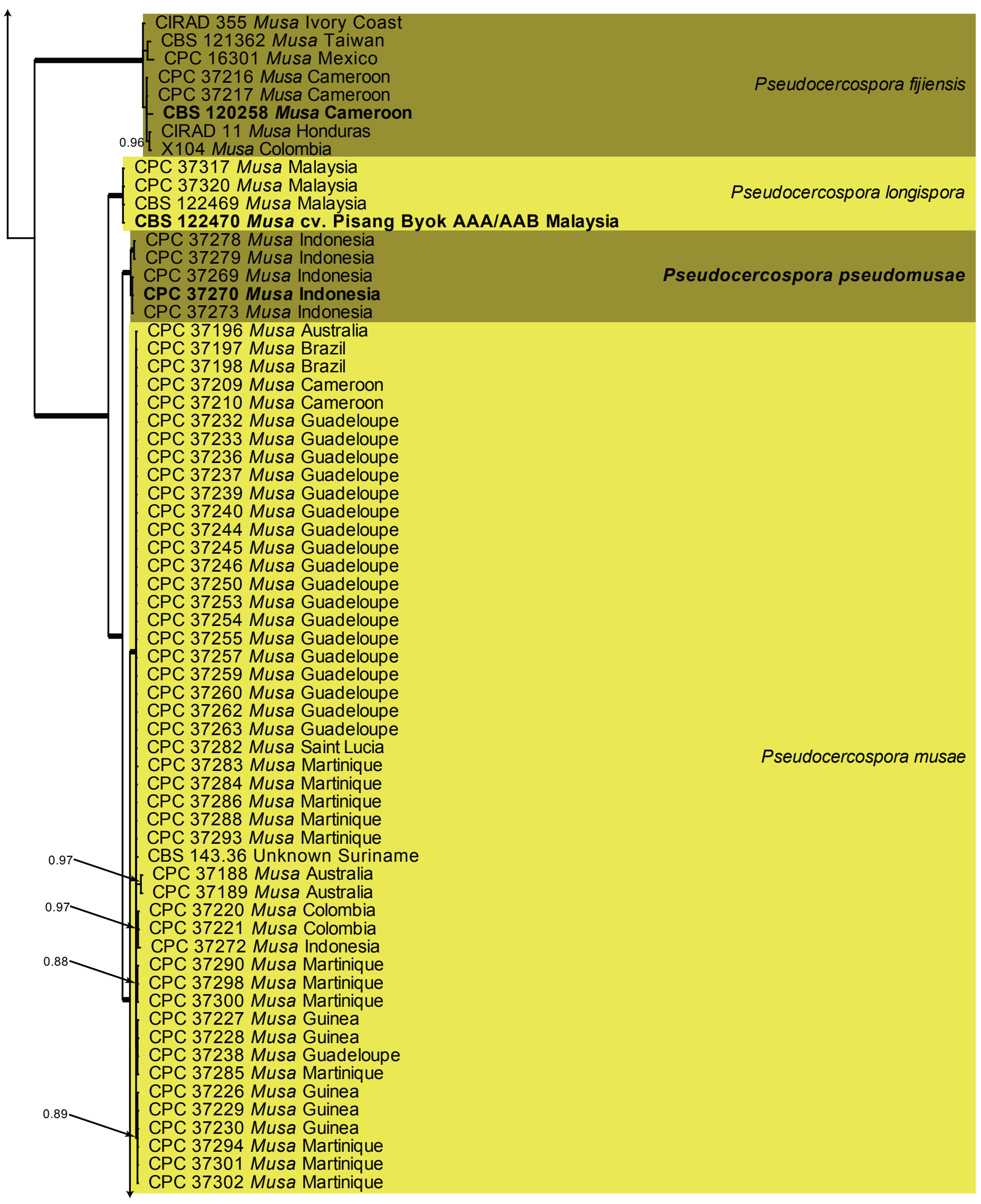

0.05

Fig. 1. (Continued). 
Pseudocercospora musae (continued)

CPC 37264 Musa Guadeloupe CPC 37265 Musa Guadeloupe CPC 37266 Musa Guadeloupe CPC 37267 Musa Guadeloupe CPC 37268 Musa Guadeloupe CPC 37280 Musa Jamaica CPC 37281 Musa Jamaica CPC 37289 Musa Martinique CPC 37292 Musa Martinique CPC 37296 Musa Martinique CPC 37299 Musa Martinique CPC 37310 Musa Venezuela PM11 Musa AAA Honduras X596 Musa cv. SH-3362 AA Australia X602 Musa cv. Lakatan Australia CPC 37192 Musa Australia CPC 37311 Musa Venezuela CPC 37276 Musa Indonesia CPC 37277 Musa Indonesia CPC 37231 Musa Guadeloupe CPC 37287 Musa Martinique CPC 37303 Musa Martinique CPC 37225 Musa Guinea CPC 37291 Musa Martinique CPC 37295 Musa Martinique CBS 116634 Musa Cuba

$0.96 \checkmark$ CPC 37193 Musa Australia X588 Musa cv. Williams Australia CPC 37186 Musa Australia CPC 37187 Musa Australia CPC 37194 Musa Australia

0.05

Fig. 1. (Continued). 
Pseudosigmoidea excentrica CBS 469.95

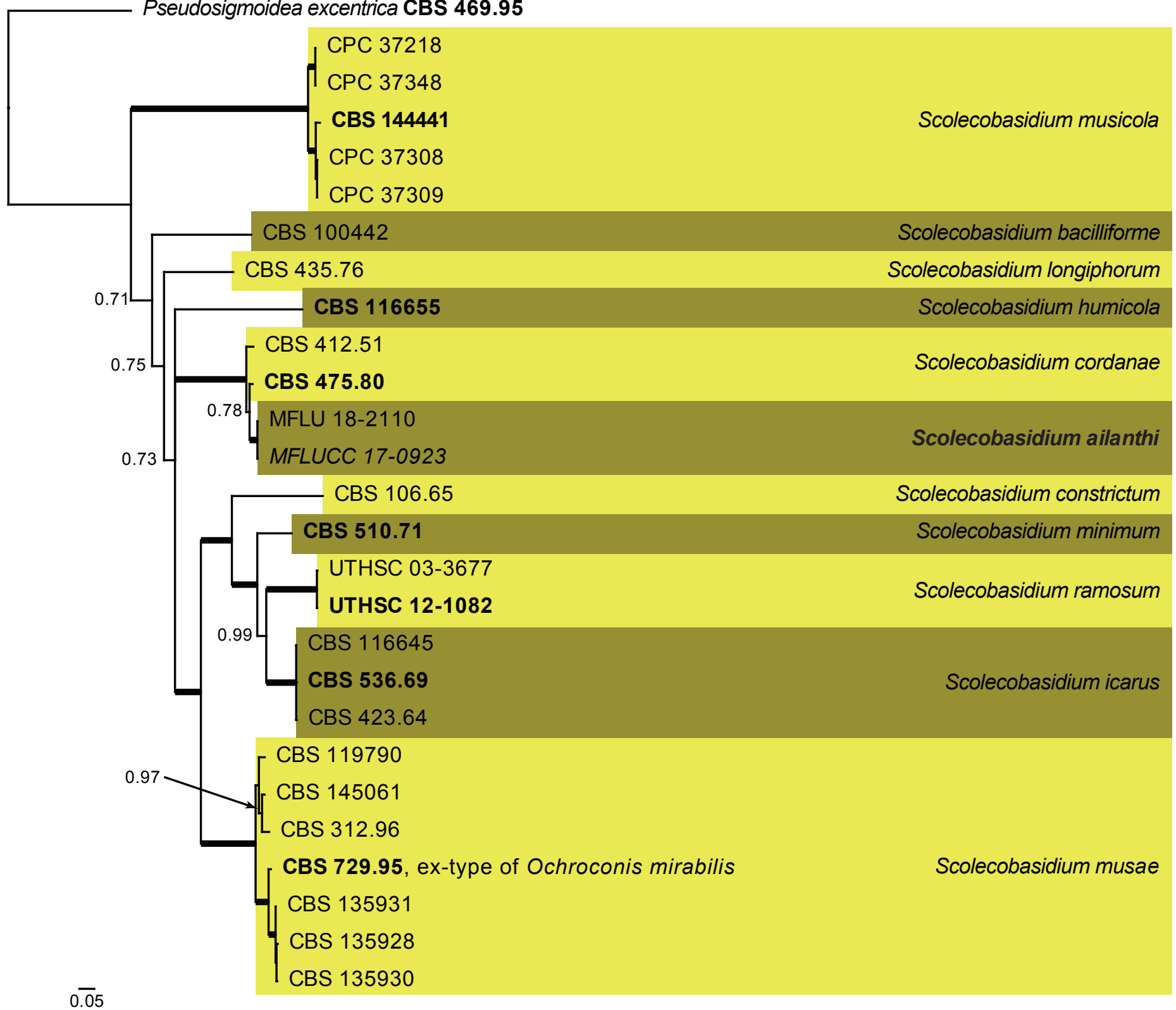

Fig. 2. Consensus phylogram ( $50 \%$ majority rule) resulting from a Bayesian analysis of the multigene Scolecobasidium sequence alignment. Bayesian posterior probabilities (PP) $>0.70$ are shown at the nodes and thickened lines represent nodes with PP $=1.00$. The scale bar represents the expected changes per site. Species are indicated with coloured blocks to the right of the tree. The tree was rooted to Pseudosigmoidea excentrica (= Scolecobasidium excentricum; culture CBS 469.95). The taxonomic novelty described in this study and the cultures with a type status are indicated in bold face.

Table 2. Substitution models and other statistical measures used for Bayesian analyses in this study.

\begin{tabular}{|c|c|c|c|c|c|c|c|c|}
\hline \multirow[t]{2}{*}{ Analysis } & \multirow{2}{*}{$\begin{array}{l}\text { Number } \\
\text { of ingroup } \\
\text { sequences }\end{array}$} & \multirow{2}{*}{$\begin{array}{l}\text { Number of } \\
\text { generations }\end{array}$} & \multirow{2}{*}{$\begin{array}{l}\text { Number } \\
\text { of trees } \\
\text { used }\end{array}$} & \multicolumn{5}{|c|}{${ }^{1}$ Substitution models used for Bayesian analyses; Number of unique site patterns } \\
\hline & & & & ITS & act & $r p b 2$ & tef1 & tub2 \\
\hline Ochroconis & 26 & 100000 & 15002 & $\mathrm{GTR}+\mathrm{I}+\mathrm{G} ; 462$ & $\mathrm{HKY}+\mathrm{G} ; 186$ & - & $\mathrm{HKY}+\mathrm{I}+\mathrm{G} ; 332$ & GTR+I+G; 262 \\
\hline Pseudocercospora & 184 & 6680000 & 100202 & $\mathrm{HKY}+\mathrm{I} ; 75$ & $\mathrm{HKY}+\mathrm{G} ; 69$ & $\mathrm{GTR}+\mathrm{I} ; 178$ & $\mathrm{HKY}+\mathrm{G} ; 183$ & - \\
\hline
\end{tabular}

${ }^{1}$ ITS: internal transcribed spacer regions and intervening 5.8S nrRNA gene; act: partial actin gene; tef1: partial translation elongation factor 1-alpha gene; rpb2: partial DNA-directed RNA polymerase II second largest subunit; tub2: partial beta-tubulin gene. 


\section{Taxonomy}

Pseudocercospora pseudomusae Crous \& Carlier, sp. nov. MycoBank MB837605. Fig. 3.

Etymology: Name reflects the genetic similarity to Pseudocercospora musae.

Colonies sporulating on PDA. Conidiophores aggregated in dense fascicles forming sporodochia on agar surface; consisting of septate, medium brown, thin-walled, smooth, subcylindrical conidiophores frequently branched below, 20-60 × 3-5 $\mu \mathrm{m}$. Conidiogenous cells integrated, terminal and intercalary, proliferating sympodially, subcylindrical, smooth, olivaceous, 13-20 × 3-4 $\mu \mathrm{m}$. Conidia solitary, olivaceous, thin-walled, smooth, subcylindrical, straight to curved, apex obtuse, base truncate, $(60-) 70-80(-100) \times(2.5-) 3 \mu \mathrm{m},(2-) 4-5(-6)$-septate.

Culture characteristics: Colonies erumpent, spreading, surface folded, with sparse to moderate aerial mycelium and even, lobate margins, reaching $8 \mathrm{~mm}$ after $2 \mathrm{wk}$ at $25^{\circ} \mathrm{C}$ in the dark. On MEA and PDA surface olivaceous grey, reverse iron-grey. On OA surface olivaceous grey with diffuse yellow pigment in agar (more prominent in isolates CPC 37273, 37378 and 37279).

Typus: Indonesia, on leaves of Musa sp., 1988, J. Carlier (holotype CBS H-24557, culture ex-type CPC 37270 = IDN 02 = CBS 147147).

Additional materials examined: Indonesia, on leaves of Musa sp., 1988, J. Carlier CPC 37269 = IDN 01 = CBS 147148; on leaves of Musa sp., 1988, J. Carlier, $37273=$ IDN 29 = CBS 147149; on leaves of Musa sp., 1989, J. Carlier, CPC $37278=$ IDN $57=$ CBS 147150, CPC $37279=$ IDN 58 $=$ CBS 147151 .

Notes: Pseudocercospora pseudomusae is closely related to $P$. musae, which has more obclavate-cylindrical conidia, that are $(10-) 20-80(-110) \times(2-) 2.5-5(-6) \quad \mu \mathrm{m}, \quad(0-) 2-7(-9)$-septate (Braun et al. 2014). Conidia of $P$. pseudomusae differ in being more subcylindrical (not obclavate), and on average being longer than those of $P$. pseudomusae.

The five isolates of $P$. pseudomusae clustered together with full support in the multi-gene phylogeny (Fig. 1). In the individual gene phylogenies based on distance and parsimony analyses (data not shown), the species can be distinguished from $P$. musae based on ITS and rpb2 while the distinction is less welldefined for tef 1 and the strains are intermingled on act. The ITS sequence of CPC 37270 is 455/468 (97\%, including one indel) to $460 / 468$ ( $98 \%$, no indels) similar to the included $P$. musae ITS sequences. The act sequence of CPC 37270 is 545/550 (99\%, no indels) to $498 / 501$ (99\%, no indels) similar to the included P. musae act sequences. The rpb2 sequence of CPC 37270 is $588 / 592$ (99\%, no indels) to $647 / 650$ (99 \%, no indels) similar to the included $P$. musae rpb2 sequences. The tef1 sequence of CPC 37270 is $448 / 453$ (99 \%, no indels) to $449 / 453$ (99\%, no indels) similar to the included $P$. musae tef1 sequences.

Several of the isolates associated leaf speckle turned out to be representative of the genus Scolecobasidium, which together with its generic synonym, Ochroconis, were recently treated by Shen et al. (2020). All species of Ochroconis for which DNA data are available have since been transferred to Scolecobasidium, except $O$. ailanthi, which is thus treated below.

Scolecobasidium ailanthi (Jayasiri et al.) Crous, comb. nov. MB837607.

Basionym: Ochroconis ailanthi Jayasiri et al., Mycosphere 10: 171. 2019.

Description and illustration: Jayasiri et al. (2019).

\section{List of Cercosporoid taxa associated with leaf spots of Musa}

Cercospora apii Fresen. (= Cercospora hayi Calp.)

Type: Musa paradisiaca var. sapientum, Cuba (ex-type culture of C. hayi, ATCC 12234); Musa cv. Cavendish, India (CBS H-20035, culture CBS 119395).

Disease: Leaf spots.

Reference: Groenewald et al. (2013).

Cercospora musae var. paradisiaca Bat. \& R. Garnier

Type: Musa paradisiaca, Brazil.

Disease: Leaf spots.

Reference: Braun et al. (2014).

[Not known from culture.]
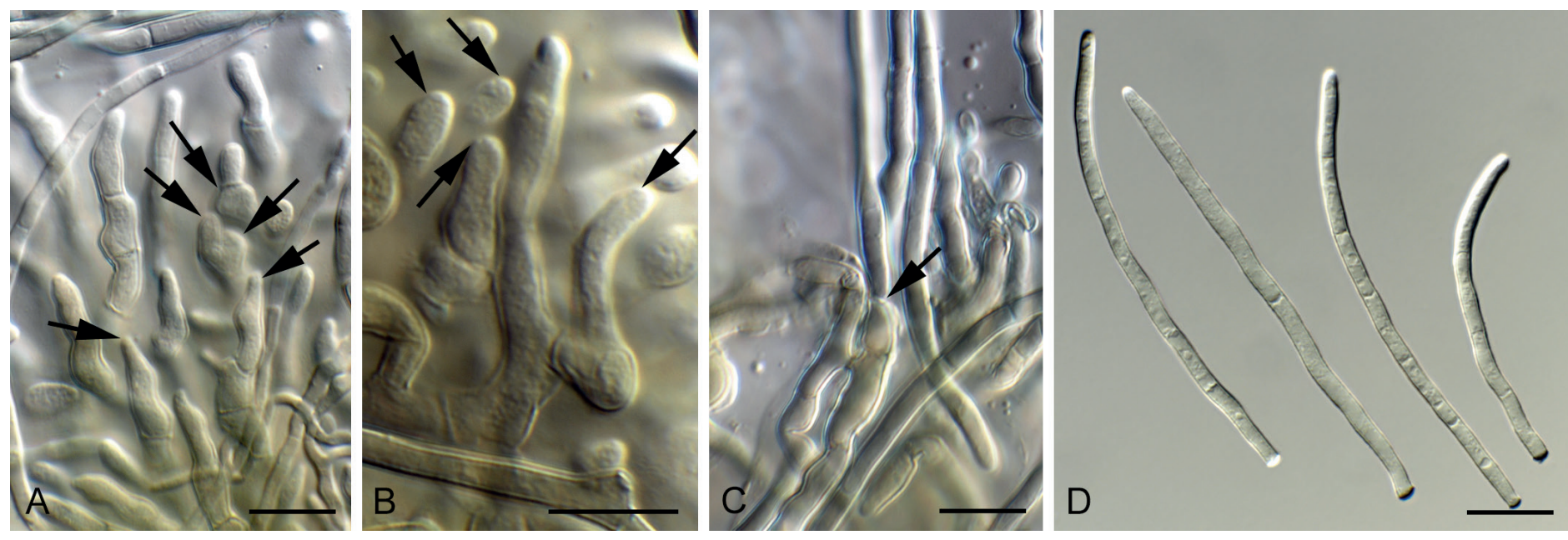

Fig. 3. Pseudocercospora pseudomusae (CPC 37270). A-C. Conidiogenous cells giving rise to conidia (arrows indicate loci). D. Conidia. Scale bars $=10$ $\mu \mathrm{m}$. 
Cercospora pingtungensis T.Y. Lin \& J.M. Yen

Type: Musa acuminata, M. cavendishii, China, Taiwan.

Disease: Leaf spots.

Reference: Braun et al. (2014), tentatively reduced to synonymy with Pseudocercospora fijiensis.

[Not known from culture.]

Cladocillium musae Chun-Hao Chen \& R. Kirschner Type: Musa itinerans, Taiwan (TNM, culture BCRC FU30634). Disease: Not associated with distinct leaf spots; secondary coloniser.

Reference: Chen et al. (2020).

Metulocladosporiella chiangmaiensis Y. Marín, Cheew. \& Crous Type: Thailand, Musa sp. (holotype CBS H-23393, culture extype CBS 143918 = CPC 18646).

Disease: Metulocladosporiella leaf speckle.

Reference: Marin-Felix et al. (2019).

\section{Metulocladosporiella malaysiana Y. Marín \& Crous}

Type: Malaysia, Musa sp. (holotype CBS H-23394, culture extype CBS 143919 = CPC 18131).

Disease: Metulocladosporiella leaf speckle.

Reference: Marin-Felix et al. (2019).

Metulocladosporiella musae (E.W. Mason) Crous et al. (= Cladosporium musae E.W. Mason)

Type: Honduras, Musa sp. (epitype CBS H-14788, CBS $161.74=$ ATCC 36973).

Disease: Metulocladosporiella leaf speckle.

Reference: Marin-Felix et al. (2019).

Metulocladosporiella musicola Crous, Schroers \& J.Z. Groenew. Type: Africa, Musa acuminata subgr. Cavendish 'Grand Nain' (holotype CBS H-14787, culture ex-type CBS 110960 = CPC 4629). Disease: Metulocladosporiella leaf speckle.

Reference: Crous et al. (2006).

Metulocladosporiella musigena Y. Marín, Cheew. \& Crous Type: Thailand, Musa sp. (holotype CBS H-23395, culture extype CBS 143920 = CPC 31490).

Disease: Metulocladosporiella leaf speckle.

Reference: Marin-Felix et al. (2019).

Metulocladosporiella samutensis Y. Marín, Luangsa-ard \& Crous Type: Thailand, Musa sp. (holotype CBS H-23396, culture extype CBS 143921 = CPC 33939).

Disease: Metulocladosporiella leaf speckle.

Reference: Marin-Felix et al. (2019).

Mycosphaerella formosana T.Y. Lin \& J.M. Yen

Type: Taiwan, Musa sp.

Disease: Leaf spots.

Reference: Aptroot (2006).

[Not known from culture.]

Mycosphaerella henriquesiana G. Winter

Type: Africa, Musa sp.

Disease: Leaf spots.

Reference: Aptroot (2006).

[Not known from culture.]
Mycosphaerella liukiuensis Sawada

Type: Taiwan, Musa formosana.

Disease: Leaf spots.

Reference: Aptroot (2006).

[Not known from culture.]

Mycosphaerella musae (Speg.) Syd. \& P. Syd.

Type: Argentina, Musa sapientum (holotype LPS, slide ex-type IMI 91165).

Disease: Leaf speckle.

Reference: Aptroot (2006), Arzanlou et al. (2008).

[Not known from culture.]

Pseudocercospora assamensis Arzanlou \& Crous

Type: India, Musa cv. Nanderan (Plantain) (holotype CBS $\mathrm{H}-20044$, culture ex-type X988 = CBS 122467).

Disease: Leaf spots.

Reference: Arzanlou et al. (2008).

Pseudocercospora eumusae Crous \& Mour. (= Mycosphaerella eumusae Crous \& Mour.)

Type: Réunion (France), Musa sp. (holotype PREM 57315, cultures ex-type $($ CIRAD 1156, $1157=C P C 4579,4580=C B S$ 114824, CBS 114825).

Disease: Eumusae leaf spot.

Reference: Crous \& Mourichon (2002).

Pseudocercospora fengshanensis (T.Y. Lin \& J.M. Yen) J.M. Yen \& S.K. Sun

Type: China, Taiwan, Musa acuminata.

Disease: Leaf spots.

Reference: Braun et al. (2014).

[Not known from culture.]

Pseudocercospora fijiensis (M. Morelet) Deighton (= Mycosphaerella fijiensis M. Morelet)

Type: Cameroon, Musa sp. (epitype CBS H-20037, culture exepitype CIRAD 86 = CBS 120258).

Disease: Black Sigatoka or black leaf streak disease.

Reference: Arzanlou et al. (2008).

Pseudocercospora indonesiana Arzanlou \& Crous

Type: Indonesia, Musa cv. Buai (holotype CBS H-20045, culture ex-type X992 = CBS 122473).

Disease: Leaf spots.

Reference: Arzanlou et al. (2008).

Pseudocercospora longispora Arzanlou \& Crous

Type: Malaysia, Musa cv. Pisang Byok AAA/AAB (holotype CBS $\mathrm{H}-20043$, culture ex-type X475 = CBS 122470).

Disease: Leaf spots.

Reference: Arzanlou et al. (2008).

Pseudocercospora musae (Zimm.) Deighton (= Mycosphaerella musicola R. Leach ex J.L. Mulder)

Type: Cuba, Musa sp. (epitype CBS H-20038, culture ex-epitype IMI 123823 = CBS 116634).

Disease: Yellow Sigatoka disease.

Reference: Arzanlou et al. (2008) 
Pseudocercospora musae-sapienti (A.K. Kar \& M. Mandal) U. Braun \& Mouch.

Type: India, Wallis, Musa paradisiaca.

Disease: Leaf spots.

Reference: Braun et al. (2014).

[Not known from culture.]

\section{Pseudocercospora musicola U. Braun}

Type: Taiwan, Musa acuminata.

Disease: Leaf spots.

Reference: Braun et al. (2014).

[Not known from culture.]

\section{Pseudocercospora pseudomusae Crous \& Carlier}

Type: Indonesia, Musa sp. (holotype CBS H-24557, culture extype CPC 37270 = IDN 02 = CBS 147147).

Disease: Leaf spots.

Reference: Present study.

Rhachisphaerella mozambica (Arzanlou \& Crous) Videira \& Crous (= Mycosphaerella mozambica Arzanlou \& Crous)

Type: Mozambique, Musa sp. (holotype CBS H-20039, culture ex-type X34 = CBS 122464).

Disease: Leaf spots.

Reference: Arzanlou et al. (2008), Videira et al. (2017).

Scolecobasidium musae G.Y. Sun \& Lu Hao [= Ochroconis musae (G.Y. Sun \& Lu Hao) Samerp. \& de Hoog]

Type: China, Musa basjoo (holotype HMAS 243664, culture extype CGMCC $3.14990=0$ HLHKBJ-22).

Disease: Leaf speckle.

Reference: Samerpitak et al. (2015).

Scolecobasidium musicola (Crous) Crous, M. Shen \& Y. Zhang ter (= Ochroconis musicola Crous)

Type: Malaysia, Musa sp. (holotype CBS H-23562, culture extype CBS 144441).

Disease: Leaf speckle.

Reference: Shen et al. (2020).

Uwebraunia musae (Arzanlou \& Crous) Crous (= Dissoconium musae Arzanlou \& Crous)

Type: India, Musa cv. Nendran (Plantain) AAB (holotype CBS H-20036, culture ex-type X1021 = CBS 122453).

Disease: Leaf spots.

Reference: Arzanlou et al. (2008).

Zasmidium biverticillatum (Arzanlou \& Crous) Videira \& Crous (= Ramichloridium biverticillatum Arzanlou \& Crous)

Type: Surinam, Musa sapientum (reference strain CBS 335.36).

Disease: Zasmidium leaf speckle.

References: Arzanlou et al. (2007), Videira et al. (2017).

Zasmidium ducassei (R.G. Shivas et al.) Y. Marín \& Crous (= Ramichloridium ducassei R.G. Shivas et al.)

Type: Australia, Musa acuminata $\times$ balbisiana (holotype and extype culture BRIP 53367).

Disease: Zasmidium leaf speckle.

References: Shivas et al. (2011), Marin-Felix et al. (2019).
Zasmidium musae (Arzanlou \& Crous) Crous \& U. Braun (= Stenella musae Arzanlou \& Crous)

Type: Tonga, Wind Ward Isles, Musa cv. TU8 AAAA, Musa cv. (holotype CBS H-20047, culture ex-type X745 = CBS 122477).

Disease: Zasmidium leaf speckle.

Reference: Arzanlou et al. (2008).

Zasmidium musae-banksii Videira \& Crous (= Ramichloridium australiense Arzanlou \& Crous)

Type: Australia, Musa banksii (holotype CBS H-19928, culture extype CBS 121710).

Disease: Zasmidium leaf speckle.

Referencse: Arzanlou et al. (2007), Videira et al. (2017).

Zasmidium musicola (Arzanlou \& Crous) Crous \& U. Braun (= Stenella musicola Arzanlou \& Crous)

Type: India, Musa cv. Grand Nain AAA (holotype CBS H-20046, culture ex-type X1019 = CBS 122479).

Disease: Zasmidium leaf speckle.

Reference: Arzanlou et al. (2008).

Zasmidium musigenum Videira \& Crous [= Ramichloridium musae (M.B. Ellis) de Hoog]

Type: Surinam, Musa sapientum (ex-type culture CBS 365.36 = JCM 6973 = MUCL 9556).

Disease: Zasmidium leaf speckle.

References: Arzanlou et al. (2007), Videira et al. (2017).

Zasmidium queenslandicum (Arzanlou \& Crous) Crous \& U. Braun (= Stenella queenslandica Arzanlou \& Crous)

Type: Australia, Musa banksii (holotype CBS H-20050, culture extype CBS 122475).

Disease: Zasmidium leaf speckle.

Reference: Arzanlou et al. (2008)

\section{DISCUSSION}

The Sigatoka leaf spot complex is the most important complex of leaf diseases of banana (Mourichon \& Fullerton 1990, Jones 2019). A revision of the taxonomy of this complex by Arzanlou et al. (2008) saw the introduction of eight new species, although their importance as foliar pathogens remains largely unknown. Many isolates that were in the past identified as $P$. musae based on general symptomatology, are now ascribed to one of these new taxa. The aim of the present study, therefore, was to revisit a global set of 228 isolates identified as $P$. musae, $P$. eumusae or other close relatives based on preliminary morphological analysis and ITS sequencing, and resolve their identity by employing multigene DNA sequence analysis and deep morphological observations. Based on these results (Fig. 1), 48 isolates were confirmed as $P$. eumusae, from India, Malaysia, Mauritius, Nigeria, Réunion (France), Sri Lanka, Thailand and Vietnam, while 104 isolates originally identified as P. musae were confirmed as this taxon from Australia, Brazil, Cameroon, Colombia, Costa Rica, Cuba, Guadeloupe, Guinea, Indonesia, Ivory Coast, Jamaica, Martinique (France), Saint Lucia and Venezuela, and two isolates as P. fijiensis (Cameroon), two isolates as $P$. longispora (Malaysia) and five isolates as a new species, $P$. pseudomusae, which is thus far only known from Indonesia. The remainder of the strains studied belonged to 
Zasmidium musae (five strains), Scolecobasidium musicola (four strains, Fig. 2), Parapallidocercospora thailandica (three strains), while one strain was identical to Pantospora guazumae and the last strain represented a Penicillium infection and was discarded from further analyses (Table 1). Seven strains were tentatively identified as Mycosphaerella musae (Australia, Brazil, Cameroon, Martinique and the Cook Islands) (Table 1). Although leaf speckle of Musa spp. has traditionally been ascribed to $M$. musae, this species was originally described from a sexual morph collected on Musa sapientum in Argentina, and its exact identity remains to be determined (Arzanlou et al. 2008).

Other than the Sigatoka disease complex, several other disease complexes have also recently been revised. "Cladosporium leaf speckle" was shown to be caused by several species of Metulocladosporiella (Marin-Felix et al. 2019) and should better be renamed as "Metulocladosporiella leaf speckle", and "Taiwan leaf speckle" ascribed to a complex of various Zasmidium spp. (Videira et al. 2017), which would in future be better referred to as "Zasmidium leaf speckle", as these taxa have a wider distribution than Taiwan only. Several other species also causing leaf speckle symptoms have been assigned to Scolecobasidium (Shen et al. 2020), but the majority of foliar pathogens on banana have to date simply been recorded as causing "leaf spots". A complicating factor is that many of the taxa listed here have not been recorded since they were initially described, and more needs to be done to resolve their phylogeny and ecology.

Conflict of interest: The authors declare that there is no conflict of interest.

\section{REFERENCES}

Abdollahzadeh J, Groenewald JZ, Coetzee MPA, et al. (2020). Evolution of lifestyles in Capnodiales. Studies in Mycology 95: 381-414.

Aptroot A (2006). Mycosphaerella and its anamorphs. Vol. 2. Conspectus of Mycosphaerella. [CBS Biodiversity Series no. 5.] Utrecht: CBSKNAW Fungal Biodiversity Centre.

Arzanlou M, Groenewald JZ, Gams W, et al. (2007). Phylogenetic and morphotaxonomic revision of Ramichloridium and allied genera. Studies in Mycology 58: 57-93.

Arzanlou M, Groenewald JZ, Fullerton RA, et al. (2008). Multiple gene genealogies and phenotypic characters differentiate several novel species of Mycosphaerella and related anamorphs on banana. Persoonia 20: 19-37.

Braun U, Crous PW, Nakashima C (2014). Cercosporoid fungi (Mycosphaerellaceae) 2. Species on monocots (Acoraceae to Xyridaceae, excluding Poaceae). IMA Fungus 5: 203-390.

Braun U, Nakashima C, Crous PW, et al. (2018). Phylogeny and taxonomy of the genus Tubakia s. lat. Fungal Systematics and Evolution 1: 41-99.

Chang TC, Salvucci A, Crous PW, et al. (2016). Comparative genomics of the Sigatoka disease complex on banana suggests a link between parallel evolutionary changes in Pseudocercospora fijiensis and Pseudocercospora eumusae and increased virulence on the banana host. PLoS Genetics 12(8): e1005904.

Chen C-H, Hsieh S-Y, Yeh Y-H, et al. (2020). Cladocillium musae, a new genus and species of cercosporoid fungi (Mycosphaerellaceae) on wild banana in Taiwan. Mycological Progress 19: 837-843.

Churchill ACL (2011). Mycosphaerella fijiensis, the black leaf streak pathogen of banana: progress towards understanding pathogen biology and detection, disease development, and the challenges of control. Molecular Plant Pathology 12: 307-328.

Crous PW (1998). Mycosphaerella spp. and their anamorphs associated with leaf spot diseases of Eucalyptus. Mycologia Memoir 21: 1-170. APS Press, St. Paul, MN, USA.

Crous PW, Braun U, Groenewald JZ (2007). Mycosphaerella is polyphyletic. Studies in Mycology 58: 1-32.

Crous PW, Braun U, Hunter GC, et al. (2013). Phylogenetic lineages in Pseudocercospora. Studies in Mycology 75: 37-114.

Crous PW, Gams W, Stalpers JA, et al. (2004). MycoBank: an online initiative to launch mycology into the 21st century. Studies in Mycology 50: 19-22.

Crous PW, Mourichon X (2002). Mycosphaerella eumusae and its anamorph Pseudocercospora eumusae spp. nov.: causal agent of eumusae leaf spot disease of banana. Sydowia 54: 35-43.

Crous PW, Schroers H-J, GroenewaldJZ, etal. (2006). Metulocladosporiella gen. nov. for the causal organism of Cladosporium speckle disease of banana. Mycological Research 110: 264-275.

Crous PW, Summerell BA, Carnegie AJ, et al. (2009). Unravelling Mycosphaerella: do you believe in genera? Persoonia 23: 99-118.

Crous PW, Verkley GJM, Groenewald JZ, et al. (eds) (2019). Fungal Biodiversity. [Westerdijk Laboratory Manual Series no.1.] Utrecht: Westerdijk Fungal Biodiversity Institute, Utrecht, the Netherlands.

Crous PW, Wingfield MJ, Park RF (1991). Mycosphaerella nubilosa a synonym of M. molleriana. Mycological Research 95: 628-632.

Fan XL, Bezerra JDP, Tian CM, et al. (2018). Families and genera of diaporthalean fungi associated with canker and dieback of tree hosts. Persoonia 40: 119-134.

Groenewald JZ, Nakashima C, Nishikawa J, et al. (2013). Species concepts in Cercospora: spotting the weeds among the roses. Studies in Mycology 75: 115-170.

Haridas S, Albert R, Binder M, et al. (2020). 101 Dothideomycetes genomes: a test case for predicting lifestyles and emergence of pathogens. Studies in Mycology 96: 141-153.

Jayasiri SC, Hyde KD, Jones EBG, et al. (2019). Diversity, morphology and molecular phylogeny of Dothideomycetes on decaying wild seed pods and fruits. Mycosphere 10: 1-186.

Jones DR (2019). Handbook of diseases of banana, abaca and enset. Wallingford: CABI.

Katoh K, Standley DM (2013). MAFFT Multiple sequence alignment software version 7: improvements in performance and usability. Molecular Biology and Evolution 30: 772-780.

Kearse M, Moir R, Wilson A, et al. (2012). Geneious Basic: an integrated and extendable desktop software platform for the organization and analysis of sequence data. Bioinformatics 28: 1647-1649.

Marin-Felix Y, Hernández-Restrepo M, Wingfield MJ, et al. (2019). Genera of phytopathogenic fungi: GOPHY 2. Studies in Mycology 92: 43-133.

Maryani N, Lombard L, Poerba YS, et al. (2019). Phylogeny and genetic diversity of the banana Fusarium wilt pathogen Fusarium oxysporum $f$. sp. cubense in the Indonesian centre of origin. Studies in Mycology 92: 155-194.

Mourichon X, Fullerton RA (1990). Geographical distribution of the two species Mycosphaerella musicola Leach (Cercospora musae) and $M$. fijiensis Morelet ( $C$. fijiensis), respectively agents of Sigatoka Disease and Black Leaf Streak Disease in bananas and plantains. Fruits 45: 213-218.

Nakashima C, Motohashi K, Chen C-Y, et al. (2016). Species diversity of Pseudocercospora from Far East Asia. Mycological Progress 15: 1093-1117.

Quaedvlieg W, Binder M, Groenewald JZ, et al. (2014). Introducing the Consolidated Species Concept to resolve species in the Teratosphaeriaceae. Persoonia 33: 1-40. 
Rayner RW (1970). A Mycological Colour Chart. Kew: Commonwealth Mycological Institute.

Ronquist F, Teslenko M, Van der Mark P, et al. (2012). MrBayes 3.2: Efficient Bayesian phylogenetic inference and model choice across a large model space. Systematic Biology 61: 539-542.

Samerpitak K, Duarte APM, Attili-Angelis D, et al. (2015). A new species of the oligotrophic genus Ochroconis (Sympoventuriaceae). Mycological Progress 14: 1-10.

Shen M, Zhang JQ, Zhao LL, et al. (2020). Venturiales. Studies in Mycology 96: 185-308.

Shivas RG, Grice KRE, Young AJ (2011). Ramichloridium spp. on Musa in northern Queensland: introducing Ramichloridium ducassei sp. nov. on leaf streaks of Ducasse banana. Australasian Plant Pathology 40: 61-65.

Simmonds NW (1962). The Evolution of the Bananas. Tropical Science Series. London, UK: Longman Publishers.

Stainton D, Martin DP, Muhire BM, et al. (2015). The global distribution of Banana bunchy top virus reveals little evidence for frequent recent, human-mediated long-distance dispersal events. Virus Evolution 1(1): vev009.
Swofford DL (2003). PAUP*. Phylogenetic Analysis Using Parsimony (*and other methods). Version 4. Sinauer Associates, Sunderland, Massachusetts.

Videira SIR, Groenewald JZ, Braun U, et al. (2016). All that glitters is not Ramularia. Studies in Mycology 83: 49-163.

Videira SIR, Groenewald JZ, Nakashima C, et al. (2017). Mycosphaerellaceae - chaos or clarity? Studies in Mycology 87: 257-421.

Zapater M-F, Abadie C, Pignolet L, et al. (2008). Diagnosis of Mycosphaerella spp., responsible for Mycosphaerella leaf spot diseases of bananas and plantains, through morphotaxonomic observations. Fruits 63: 389-393.

Zhang Z, Schwartz S, Wagner L, et al. (2000). A greedy algorithm for aligning DNA sequences. Journal of Computational Biology 7: 203214. 